\title{
Petrology of Mg-bearing Meta Ophiolite Complexes of Qaen-Gazik,
} Eastern Iran

\section{Fatemeh Gharib-Gorgani*, Afshin Ashja- Ardalan', Mohammad-Reza Espahbod', Seyed-Jamal Sheikhzakariaee ${ }^{2}$, Abdollah Yazdi $^{3}$}

${ }^{1}$ Department of Geology, North Tehran Branch, Islamic Azad University, Tehran, Iran

${ }^{2}$ Department of Geology, Science and Research Branch, Islamic Azad University, Tehran, Iran

${ }^{3}$ Department of Geology, Islamic Azad University, Kahnooj Branch, Kerman, Iran

Study Area: South Khorasan province, Iran

Coordinates: $32^{\circ} 59^{\prime} 11.5^{\prime \prime}$ to $33^{\circ} 39^{\prime} 54^{\prime \prime} \mathrm{N} \& 60^{\circ} 13^{\prime}$ $2.2^{\prime \prime}$ to $59^{\circ} 11^{\prime} 13.3^{\prime \prime} \mathrm{E}$

Key words: Geochemistry, Eastern Iran

\section{Abstract}

The ophiolitic complex that studied in this piece of work is the part of an ophiolite ring surrounding Central Iran, emplaced during the Mesozoic related to divisions of Young Tethys types. According to the point analyses performed on the plagioclases and pyroxenes, all pyroxenes of the area are of high-Ca augite type. From labradorite to anorthite, plagioclases are the most dominant phenocryst in all rocks of the area. According to geochemical diagrams, it was concluded that the studied ophiolite complex is of harzburgite type (H-type) and its emplacement model corresponds with a cordilleran model of ophiolite emplacement. Although this ophiolite is of Tethys types, thus it could be stated that most of the parts of ophiolite sequence of the area were undergone metamorphism. Thus according to metamorphism of parts of basal peridotites of the ophiolite, metamorphosed ophiolite is an ideal name for this ophiolite suite.

undergone alteration and re-mineralization. Alteration is of silicic-carbonate type and occasionally argillic alteration and impregnation of iron oxide occur in its margins. Host rock of this unit is predominately ultrabasic rocks (ub) (Figures 2 \& 3 ).

3- Flysch, lime and turbidit sediments (PaleoceneEocene): During Paleocene-Eocene, erosion rate increased due to rising resulted from collusion and tectonic pressures in surrounding territories that resulted in formation of the flysch zone in the east of the Qaen quadrangle (the flysch of Eastern Iran) and in turn in the study area. Flysches were formed predominately from sandstones, shales, limestones, tuffs and turbiditic sediments and often formed low topography (excluding limestone occurrences).

\section{Lithology:}

In general, most of the outcropped lithology in the studied ophiolite suite includes two rock types of mafic and ultramafic rocks. Basic rocks of the region include pillow lavas in grey colour characterised by abundant radial fractures, amygdaloidal vesicles full of secondary iron oxides formed due to the gas explosion and altered margins. Moreover, the existence of low amounts of breccia and pelagic sediments in interstitial voids of pillow lavas is another characteristic of these lavas. These lavas 
contain abundant plagioclase, clinopyroxene and little amount of opaque mineral in fine-grained microlithic or vitreous context. They were more or less metamorphosed due to undergoing sea floor static pressure that is demonstrated by secondary minerals of epidote, chlorite, prehnite, sericite, calcite and quartz. Voids of these rocks are filled by secondary minerals of calcite, quartz and chlorite. Microscopic sections obtained from these rock units indicate the presence of phenocrysts of olivine and phenocrysts and microliths of plagioclases in the microcrystalline context of these minerals. Dominant occurred textures in these sections include porphyry, glomoroporphyry and the intersertal. Glomoroporphyry texture resulted from the accumulation of plagioclase, clinopyroxene and olivine. According to Kirkpatrick (1977), accumulation of minerals and formation of glomerol may be due to the heterogeneous conception of these minerals. Plagioclase with polysynthetic macle is the most abundant mineral existed in the background that often occurs in microlitic and blade form. Rounded and hypidiomorphic crystals consist about $15 \%$ of these rocks to such an extent that these rocks could be called olivinebasalt. Regarding the frequency and phase relation appeared in microscopic sections of olivine basalts of the regions, the crystallisation order of constituting minerals of these rocks can be given as following:

$$
\mathrm{Ol} \rightarrow \mathrm{Ol}+\mathrm{Pl}+\text { Opaque } \rightarrow \mathrm{Cpx}
$$

Gabbroes: in the ophiolite sequence of the region, gabbros are situated under peridotites. Most of the gabbroic rocks are massive and occasionally layered which are ranged from locogabbroes to melagabbroes. Paragenesis of locogabbroes in thin sections includes labradorite $(60 \%)$, diopside to augite $(30 \%)$, orthoclase $(5 \%)$ and quartz (5\%). Paragenesis of melagabbroes in thin sections includes labradorite (35\%), diopside to augite $(50 \%)$, orthoclase $(8 \%)$ and quartz $(7 \%)$. These rocks are coarse-grained (pegmatoid), medium-grained and finegrained and occur as the dyke and massive bodies. Petrographic studies of these rocks indicate the presence of euhedral and anhedral ophitic and granular textures. In hand specimens, their granular fabric is easilyvisible.

Wehrlite: it occurs as small intrusive bodies scattered in the area. These rocks show granular and ophitic textures and their major minerals are olivines, clinopyroxene, orthopyroxene and plagioclase. Olivine crystals are mostly altered to serpentine. Clinopyroxene crystals occur as subhedral to anhedral that consists about $25 \%$ of rock and mostly of augite to diopside augite types. Moreover, as olivine, this mineral underwent advanced alteration. Petrographically, harzburgite rocks contain $75-85 \%$ olivine and $15-25 \%$ orthopyroxene (enstatite) as major minerals. Moreover, as dunite sample, chrome spinel is ordinary secondary mineral in these rocks. In the cases that the amount of this mineral increases, rocks tend to

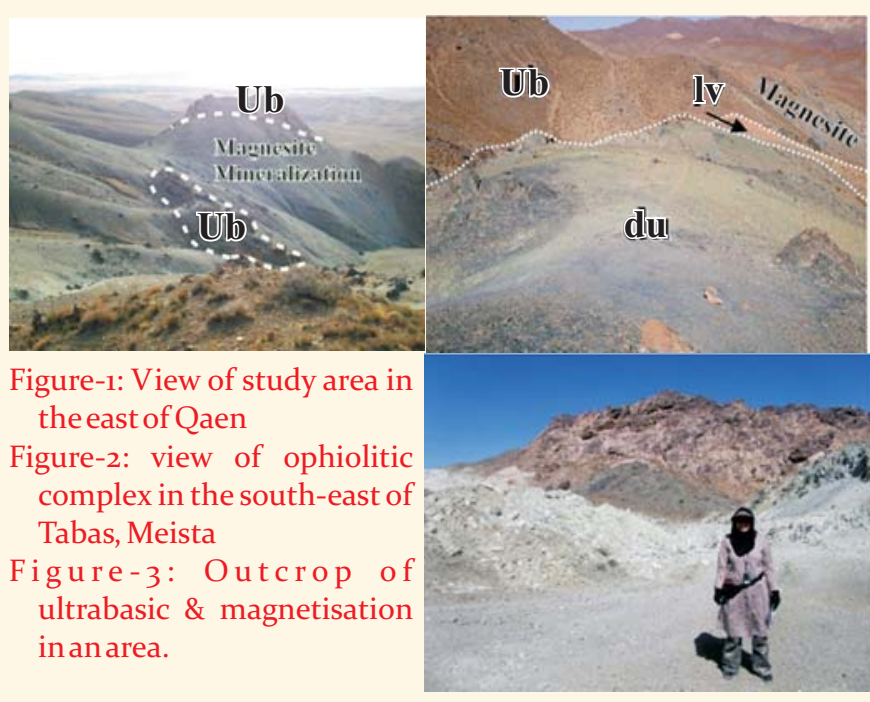

lherzolites although its frequency is little. Opaque secondary minerals of harzburgites show little frequency (chrome spinel). Serpentinization led to the formation of lattice and sieve texture of these rocks (Figure 4-a).

Pyroxenite: these rocks show little occurrence in the area and seen as small and scattered masses among peridotites rocks inside ophiolite suite and undergone rather lower alteration than other ultramafic rocks of the area. Their major minerals include diopside $(45 \%)$, enstatite $(20 \%)$ and olivine (35\%). Microscopic sections obtained from these rock show presence of orthopyroxene (enstatite), chlorite and iron oxides resulted from the alteration of pyroxene. These rocks have granular texture thus they could be called ortho pyroxenite. In some orthopyroxenes, fresh crystals of olivine are trapped. Petrographically these rocks may be called olivine websterite. Thermodynamically it could be summarised that this state may be justified in the phase diagram of binary mixtures of $\mathrm{Fe}-\mathrm{SiO}_{2}$ with the intermediate composition of En to such an extent that in peritectic point existed in this diagram, coarse crystals of Ops is formed with the expense of olivine (forsterite) and its reaction with magma. Finally due to the formation of enstatite $(\mathrm{Opx})$ haloes around olivine, its residual is saved from continuing reaction which is resulted as the present state that is seen as olivine crystal trapped inside pyroxene. Effects of filling existing joints by calcite or serpentine are seen in these rocks that resulted from serpentinization and $\mathrm{CO}_{2}$-rich solutions.

Serpentinite: under chemical alteration, peridotite rocks such as harzburgites and dunits were serpentinized and converted into serpentine. These rocks show lattice or sieve textures during microscopic observations. Residual original minerals of these rocks include olivine, spinel, orthopyroxene and clinopyroxene that occur in little amount.

Dunite: these are ultramafic rocks consisting of $90 \%$ or 

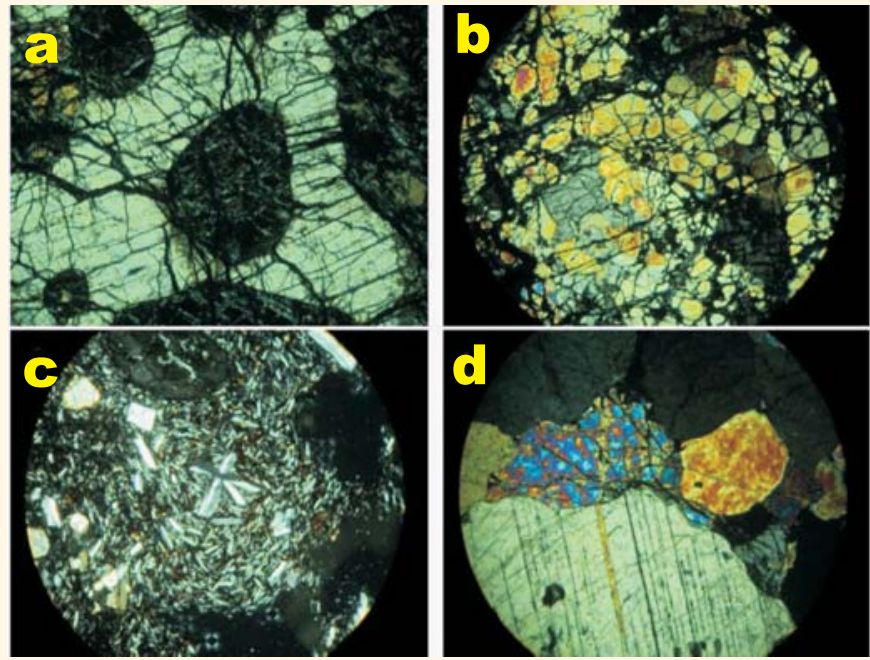

Figure 4. a) Skeleton structure of pyroxene that show clearly precedence of formation of olivine on pyroxene in a harzburgite (10oX Field Length:2.2mm ). b) Granular texture and presence of olivine mineral and serpentinization in dunite. XPL (Enlarging $100 \mathrm{X}$ ). c) Cruciate macle in plagioclases in basalt. d) pyroxene grains with Carlsbad macle in gabbro (XPL), 10oX Field Length:2.2m

more olivine and less than $10 \%$ of magnetite, chromite, orthopyroxene and clinopyroxene. Their textures are generally granular and their secondary texture has resulted from olivine serpentinization that is seen as lattice or sieve texture in thin sections. Due to the sensitivity of olivine to alteration, dunites are altered to serpentine masses as soon as the departure from their formation place that is seen clearly in the ophiolite bodies of the area (Figure 4.b).

Geochemistry: rock samples from the area are fall in calkalkaline range rich of magnesium, basalt and calk-alkaline andesite in the cationic diagram (Jensen, 1976) of Al$\left(\mathrm{Fe}^{*}+\mathrm{Ti}\right)-\mathrm{Mg}$ (Figure 5.b). According to the diagram of $\mathrm{Na}_{2} \mathrm{O}+\mathrm{K}_{2} \mathrm{O}$ versus $\mathrm{SiO}_{2}$ (Middlemost, 1985), intrusive igneous rocks of the study area are situated in the range of gabbro, gabbrodiorite, granodiorite and quartz monzonite (Figure $5 \mathrm{a}$ ). Based on $\mathrm{Na}_{2} \mathrm{O}+\mathrm{K}_{2} \mathrm{O}$ versus $\mathrm{SiO}_{2}$ (Middlemost, 1985), volcanic rocks of the area are situated in the range of basaltic-andesitic composition. High-Si value of basaltic rocks is due to the existence of quartzfilled veins and voids. According to the diagram of $\mathrm{Na}_{2} \mathrm{O}+\mathrm{K}_{2} \mathrm{O}$ versus $\mathrm{SiO}_{2}$ (Cox et al., 1979), volcanic rocks of the study area show basaltic composition and all of the samples are situated in the range of sub-alkaline series based on this diagram. Therefore diagram of $\mathrm{Zr} / \mathrm{TiO}_{2}$ versus $\mathrm{Nb} / \mathrm{Y}$ (Winchester \& Floyd, 1977) is used for more precise identification of nature of these rocks that classifies rock based on alkalinity degree. Basic samples examined in this diagram are situated in the range of alkaline basalt (Figures 6 \& 7).

Types of Ophiolite:
Ambient Science, 2017: Vol. 04(1); 01-06 DOI:10.21276/ambi.2017.04.1.ga01

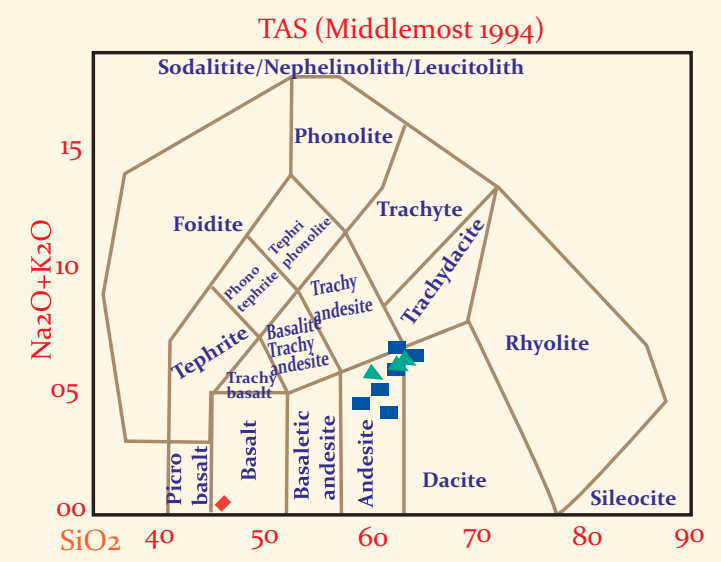

Figure 5. a) diagrams of $\mathrm{Na}_{2} \mathrm{O}+\mathrm{K}_{2} \mathrm{O}$ versus $\mathrm{SiO}_{2}$ (Middlemost, 1985) for denomination of volcanic rocks.

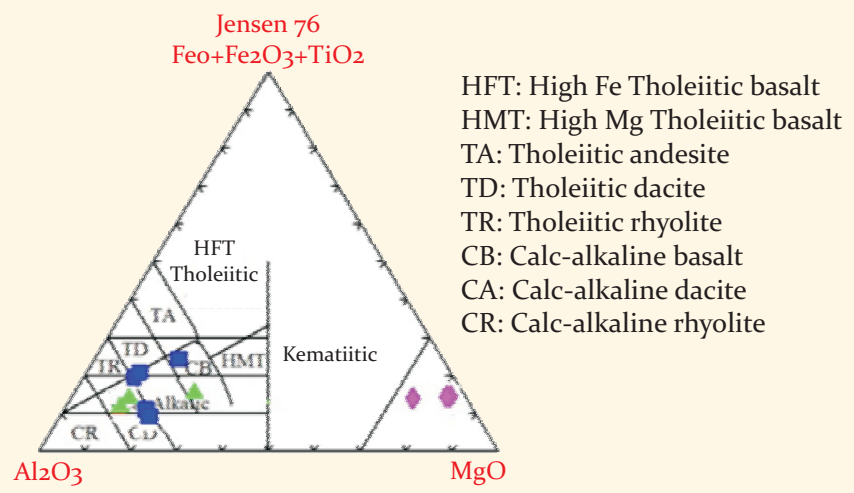

Figure 5. b) cationic diagram Al-(Fe*+Ti)-Mg (Jensen, 1976)

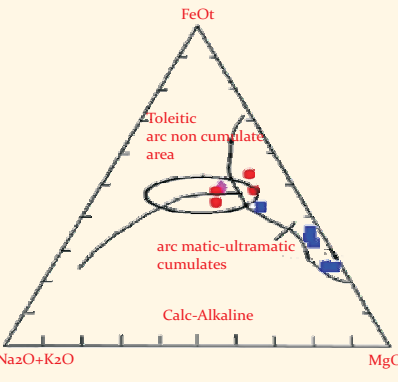

Figure-6: Triple diagram FeOt, $\mathrm{MgO}, \mathrm{Na}_{2} \mathrm{O}+\mathrm{K}_{2} \mathrm{O}$ (Beard, 1986)

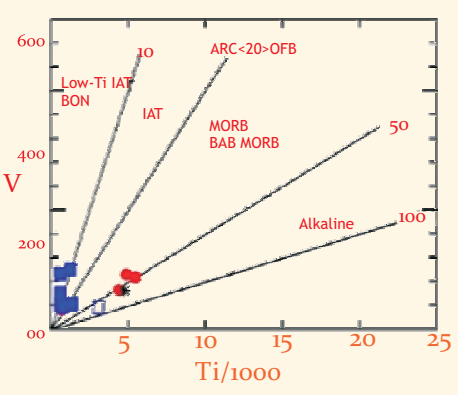

Figure 7. Diagram (Shervais, 1982)
Based on study of Irvine \& Baragar (1971) it may be concluded that the ophiolite suite of the study area is lowTi ophiolite regarding Ti amount. Since Ti amount in ophiolite rocks indicate depletion degree of mantle origin of these rocks and since high and low Ti types originated from partial melting of lherzolitic and harzburgiticdunitic mantle respectively so it may conclude that basaltic magmas forming ultrabasic and basic rocks of the area originated from melting a harzburgitic-dunitic mantle. Multi-elemental diagram normalised against condorite (Nakamura, 1974) is given for studied samples. As per the study, all samples show enrichment from light rare earth element (LREE) and depletion from high rare earth element (HREE). Since in the studied samples, the 
ratio of LREE /HREE was high and downward slope of their diagram was not so high. High concentration of incompatible elements and enriching of LREE was attributed to two low degrees of partial melting of a mantle source enriched from LREE (Wilson, 1989; Chen et al., 2002) and/or derivation from crustal alkaline mafic compositions in high degrees of partial melting that in latter, resulted melt usually of low magnesium number (<44) (Altunkaynak \& Genç, 2008). High magnesium number in the studied samples and alkaline nature of studied sample confirm low partial melting degrees of enriched mantle in the formation of rock constituting magmas (Wedepohl, 1985). Moreover, parallel changes of trace elements for the studied elements indicate the evolution of these rocks during differential crystallisation of magmas. Spider diagram forwarded by (Pearce, 1983) normalised to MORB shows enrichment of $\mathrm{Sr}, \mathrm{K}, \mathrm{Rb}, \mathrm{Ba}$, $\mathrm{Th}, \mathrm{Ta}$ and $\mathrm{Nb}$ and depletion of $\mathrm{Y}$ and $\mathrm{Yb}$. In this diagram, elements such as $\mathrm{Sm}, \mathrm{Ce}$, etc. and $\mathrm{Hf}, \mathrm{Zr}$, etc. that are belong to REE and HFSE group show enrichment in some samples and depletion in some others. In the rare earth element patterns of rocks of the area that are normalised versus NMORB, LREE elements show much higher enrichment than HREE elements. The rare earth element patterns show rather a high slope and incompatible elements such as $\mathrm{Ba}, \mathrm{Rb}$ and $\mathrm{Cs}$ show enrichment even to 100 times of NMORB values. Elements such as $\mathrm{Y}, \mathrm{Yb}$ and $\mathrm{Lu}$ show lower frequency versus NMORB in all samples that indicate their depletion. Rock samples of the area show compositions similar to EMORB and frequency of their REEs is situated in the range near to the source of NMORB. Generally, in these diagrams (EMORB-NMIRB), there is a positive anomaly in values of $\mathrm{Ti}, \mathrm{U}$ and $\mathrm{K}$ and a negative anomaly in values of $\mathrm{Sr}, \mathrm{P}, \mathrm{Nb}$ and $\mathrm{Ba}$.

Petrogenesis: triangular diagram of $\mathrm{TiO}_{2}-\mathrm{K}_{2} \mathrm{O}-\mathrm{P}_{2} \mathrm{O}_{5}$ (Pearce, 1975) was used for differentiation of oceanic basalts from continental basalts. As per the study, most of the basaltic and dibasic samples of the area situate in the oceanic range. Two samples situate in the continental range near to $\mathrm{K}_{2} \mathrm{O}$ vertex that is due to increase of this oxide in these two samples resulted from alteration.

Structural belt of Eastern Iran as part of Tethys orogenic belt has unique characteristics that discriminate it from other areas of Iran. Geologically, this part of the country is composed of the Makran mountain ranges, the Loot and Helmand blocks, ophiolitic mélange of Iranshahr-Birjand and young volcanos of Taftan and Bazman. This zone is called as Sistan suture zone by Camp and Griff is (1982) and its development is attributed to the range of process from rifting to collision. Reyre \& Mohafez (1972) cited Iranshahr-Birjand area as Flysch Basin east of Iran and metamorphisms of Eastern Loot and divide them into two orogenic parts of Neobalutch and Paleobalutch.

Stockline (1977) called this part of Iran as
Axial_opholitic zone and attribute its formation to earth extension (1985, 1991). Kari called this as Balutchistan orocline and cites this as an example of earth extension. No occurrence of formation older than Cretaceous has reported in the sedimentary basin of Eastern Iran except than areas neighboring the Loot block. Existing reliefs in the area in different trends indicate that this area enclosed in a pressure-shear zone that led to the formation of complex structural processes. From point view of Tirrul et al. (1983), this area is a result of collusion between subcontinent of Loot and the Afghan block that led to subduction of oceanic crust that existed between these two sub-continent formed from early Cretaceous under the Afghan block in the end of Cretaceous. According to the views of Camp \& Griff is (1982), Eastern Iran is a suture zone of two blocks that experienced many events during its development period.

Deformed accretionary prism and fore-arc basin are extended from the south-east of Birjand to Zahedan as an outgrowth of Neo-Tethys in the period of Cenomanian to Paleocene that is closed with the collusion of cratonic blocks of Afghan and Loot (Tirrul, et al., 1983). In the northern latitude of $32^{\circ}$, accretionary prisms are divided into two belts of a northwestern strike including Ratok and Neh. The Ratok complex is characterised in the east by tectonized plates and blocks of ophiolite and mélanges with matrix serpentine and blue schist metamorphisms. This complex was formed before Matis-Terishtin and its glaucophan schist are covered unconformally by rodositbearing limestones. Formation of complexes equivalent with Retok was continued to the north by a dilatory period up to Matis-Terishtin. This is implied by structural and tectono-stratigraphical comparison of various fields due to the performance of faults of Siah-Kamar, Esmail-Abad, Birjand, Ghaleh-Sorkh Nozad and Gazik.

The Neh complex situated in the south-east of the area is belonging to Cenonian to Eocene and in addition to ophiolites, includes rocks of marine metamorphosed deposits that outcropped in extensional belts by stepped faults. Fore-arc basins of Sefiabeh cover both the complexes of Retok and Neh together with the southwestern margin of the Afghan block. Those deposits include detrial-clastic sediments and carbonate rocks of Cenomanian to Eocene and indicate a complex with an evident stratigraphy. According to slide direction in accretionary mountains and geological setting described above, subduction slope is toward the northeast and slide slope of complexes resulted from subduction is toward the south-west. Regarding the definition presented by Dicknson \& Seely (1979), the Sephidabeh basin is of the fore-arc type that is an important part of the subduction complex. From the tectonostratigraphic point of view, this basin is compared with a wide zone of clastic facies extended in the study area from the age of Paleocene to 
GENERAL ARTICLE

Upper Eocene-Oligocene.

\section{Conclusion:}

According to performed studies and review the history of formation and development of structural zone of Eastern Iran may be summarized as:

1- There was a unit continent in this part of Iran until early Cretaceous. According to rift basin facies related to Jurassic in the south of Sahl-Abad, initiation of older extensional phases in the crust in a significant subject that must be examined. Those basins became younger from south to north although they remained barren in many wings.

2- In middle cretaceous, the study area was found to be divided into two eastern and western parts due to the formation of longitudinal cracks (rift) in such an extent that its eastern part created the Helmand block and its western part created the Loot block. The distance between these two blocks increases and a narrow ocean with ocean crust formed in their formation place.

3- With replacement and displacement of ophiolites in late cretaceous (Maes-Tristian) a weak metamorphism occurred in the turbidities of the area. This event may be related to the initiation of underlining oceanic crust under Helmand block and/or fragments of the Loot block. This type of metamorphism is observed in the faces north of Sarbisheh resulted from strike-slip and right-slip movements of the Qalehsorkh-Nozad.

4- Coinciding and collusion of the Loot block or the turbidity zone that may be occurred in Upper Cretaceous-Paleocene ended to above-mentioned underlining and resulted into an ophiolitic mélange in the east of the Loot block adjoining faults of the various mechanism.5- Gradual approaching of the Loot block and the Helmand during OligoceneMiocene led to folding, fracturing and uplifting of the area (emersion from water).

6- Volcanism due to extension and extending rift basin with alkaline-calk alkaline and pre-collusion magmatism of these blocks with calk-alkaline composition is related to dominant tectonic of extension and subduction of oceanic and continental crusts.

7- Existence of sedimentary layers in midst of volcanic eruptions indicates that early volcanic eruption occurred underwater.

8- Intensive magmatic activities in the area during Neogene were concentrated with the linear trend in the brink and margin of major faults.
Ambient Science, 2017: Vol. 04(1); 01-06 DOI:10.21276/ambi.2017.04.1.ga01

9- Alkanic and intra-continental volcanism during PlioQuaternary indicates development and formation of extensional basins in the midst of colluding orogenies.

10- Evolution of rhombohedric pull apart basin basins in midst of major faults led to the formation and development of intra-continental sedimentary basin during Quaternary.

11- Extension of barren sedimentary basins during MaesTrishtian coinciding with initiation of collusion in the north of Birjand.

12- Extension and structural development of fault in accordance with structural systems- Mud-structure Riedel.

Acknowledgements:

We are grateful to the Department of Mechanical Engineering, Jolfa International Branch, Islamic Azad University, Jolfa, Iran which assisted us to conduct this research.

\section{References:}

Aghanabati, A. (2004): Iran Geology. State Department of Geology Organization, Iran.

Altunkaynak, S., Genç, S.C. (2008): Petrogenesis and timeprogressive evolution of the Cenozoic continental volcanism in the Biga Peninsula, NW Anatolia (Turkey). Lithos. 102(1): 316-340.

Arvin, M. \& Robinson, P.T. (1994): The petrogenesis and tectonic setting of lavas from the Baft ophiolitic mélange, southwest of Kerman, Iran.Can. J. Earth Sci., 31(5):824-834.

Beard, J.S. (1986): Characteristic mineralogy of arc-related cumulate gabbros: Implications for the tectonic setting of gabbroic plutons and for andesite genesis. Geology, 14: $848-851$.

Camp, V.E. \& Griffis, J. (1982): Character, genesis and tectonic setting of igneous rocks in the Sistan Suture Zone, Eastern Iran. Lithos, 15:221-39.

Chen. B., Jahn, B.M. \& Wei, C.J. (2002): Petrogenesis of Mesozoic granitoids in the Dabie UHP complex, central China: trace element and Nd-Sr isotope evidence. Lithos, 6o:67-88

Cox, K.G., Bell, J.D. \& Pankhurts, R.J. (1979): The interpretation of igneous rocks. Pub. by: Springer/Chapman \& Hall.

Dickinson, W.R. \& Seely, D.R. (1979): Structure and stratigraphy of fore-arc region. Am. Asso. Petr. Geol. Bull., 63:2-31

Irvin, T.N. \& Baragar, W.R.A. (1971): A guide to the chemical classification of the common volcanic rocks. Can. J. Earth Sci., 8: 523-548.

Jensen, L.S. (1976): A new caption plot for classifying subalkanic volconic rocks. Ontario Division of Mines Miscleneous Paper. 66 p.22

Knipper, A., Ricou, L.E. \& Dercourt, J. (1986): Ophiolites as indicators of the geodynamic evolution of the Tethyan ocean. Tectonophysics, 123: 213-240.

Kirkpatrick R. J. (1977): Nucleation and growth of plagioclase, Makaopuhi and Alae lava lakes, Kilauea Volcano, Hawaii. Geol. Soc. Am. Bull., 88:78-84. 
Middlemost, E.A.K. (1985): Magmas and magmatic rocks. Pub. by: Longman, London.

Nakamura, N. (1974): Determination of REE, Ba, Fe, Mg, Na, and K in carbonaceous and ordinary chondrites. Geochim. Cosmochim. Ac., 38:757-775.

Pearce, J.A. (1975): Role of the sub-continental lithosphere in magma genesis at active continental margins. In: Hawkesworth,C.J., Norry, M.J. (Eds.), Continental Basalts and Mantle Xenoliths, (Shiva Geology Series). Pub.: Birkhäuser.

Pearce, J.A. (1983) Role of the sub-continental lithosphere in magma genesis at active continental margins. In C.J Hawkesworth and M.J. Norry, (Eds.), Continental basalts and mantle xenoliths, p. 230-249. Shiva, Orpington (Iondon), and Birkhauser Boston, Cambridge, Massachusett.

Reyer, D. \& Mohafez, S.A. (1972): First Contribution of the NIOC-ERAP Agreements to the Knowledge of Iranian Geology. Edition Techniqs, Paris, 58 p.
Shervais, J.W. (1982): Ti-V plots and the petrogenesis of modern ophiolitic lavas. Earth Planet. Sci. Lett. 59: 101-118.

Stocklin, J. (1977): Structural correlation of the Alpine ranges between Iran and central Asia. Memoire Hors Serie, 1(8):333353.

Tirrul, R., Bell, I.R., Griffith, R.J. \& Camp, V.E. (1983): The Sistan suture zone of eastern Iran. Geol. Soc. Am. Bull. 94:134-150

Wedepohl, K.H. (1985): Origin of the Tertiary basaltic volcanism in the Northern Hessian depression. Contrib. Mineral. Petr. 89:122-143.

Wilson, M. (1989): Igneous peterogenesis. A global approach. Pub. by: Unwin, Hyman, London, p. 465.

Winchester, J.A. \& Floyd, P.A. (1977): Geochemical discrimination of different magma series and their differentiation products using immobile elements. Chem. Geol., 20(4):325-343. 